\title{
ANÁLISE COMPARATIVA DO CONHECIMENTO SOBRE TOXOPLASMOSE DOS PROFESSORES DE ESCOLAS DA REDE MUNICIPAL DAS SÉRIES INICIAIS DO ENSINO FUNDAMENTAL DO MUNICÍPIO DE JATAÍ-GO, BRASIL
}

(COMPARATIVE STUDY OF THE KNOWLEDGE ABOUT TOXOPLASMOSIS OF TEACHERS OF MUNICIPAL SCHOOLS OF THE INITIAL SERIES OF ELEMENTARY SCHOOL IN JATAÍ-GO, BRAZIL)

\section{J. C. DIAS ${ }^{1}$, E. M. N. PAULA ${ }^{1}$, D. A. AZEVEDO ${ }^{1}$, D. P. ARAÚJO ${ }^{1}$, D. B. SOUSA ${ }^{2}$, R. B. MEIRELLES-BARTOLI ${ }^{*}$}

Antropozoonose transmitida pelo Toxoplasma gondii por ingestão de oocistos, cistos teciduais, e transplacentariamente. Os felídeos são hospedeiros definitivos. Mamíferos e aves hospedeiros intermediários. Informar professores é o passo inicial para formar multiplicadores. Objetivou-se comparar o conhecimento prévio e assimilação das informações sobre toxoplasmose através de palestras aos professores de todas as escolas municipais de Jataí - GO. Foram entrevistados 165 docentes de 19 instituiçães. Um questionário com perguntas abertas sobre transmissão e prevenção foi aplicado antes e após a palestra. Do total, 18,8\% (31/165) não responderam as perguntas, diminuindo para 6,6 \% (11/165) após palestra. Comparando as respostas nos dois momentos pode-se observar: previamente $31,3 \%$ (42/134) não sabiam explicar a transmissão, depois 10,4\% (16/154); contato com as fezes do gato de 40,2\% (54/134) para 46,8\% (72/154). Contato com cães e gatos de 14,9\% (20/134) e depois 6,5\% (10/154) responsabilizava outros animais; ingestão de alimentos 9,7\% (13/134) e depois não mais; falta de higiene e ambientes contaminados de 2,9\% (4/134) para 3,2\% (5/154). E contato com rato de $0,7 \%$ (1/134) para 1,3\% (2/154). Novas respostas sugiram: água e alimentos contaminados $13 \%$ (20/154), animais e alimentos contaminados 9,1\% (14/154); fezes de gato e carne contaminada 9,7\% (15/154). Sobre prevenção, 57,4\% (77/134) não souberam explicar, reduzindo para 16,9\% (26/154); vacinação dos animais de 11,9\% (16/134) para 5,8\% (9/154), sem especificar se em humanos ou animais; evitar contato com animais infectados de 14,1\% (19/134) para 5,2\% (8/154); higiene básica de 9,7\% (13/134) para 35,7\% (55/154). Evitar o contato com gatos e com ratos foi citado apenas antes por $6 \%$ (8/134) e $0,7 \%$ (1/134), respectivamente. Novas respostas surgiram: $22,1 \%$ (34/154) consumo de alimentos crus; 9,7\% (15/154) evitar contato com animais infectados e alimentos crus; e 4,5\% (7/154) outros. Concluiu-se que apesar da melhora nas respostas, ainda há necessidade de trabalho de orientação em relação à transmissão e prevenção de importantes zoonoses.

\footnotetext{
${ }^{1}$ Alunos do Curso de Medicina Veterinária da Universidade Federal de Goiás, Campus Jataí.

${ }^{2}$ Docentes do Curso de Medicina Veterinária da Universidade Federal de Goiás/Campus Jataí, Unidade Jatobá, Laboratório de Sanidade Animal. ${ }^{2 *}$ E-mail: raphaellabrasil@ hotmail.com
} 